\title{
The Influence of Pr and Nd Substitution on Hydrogen Storage Properties of Mechanically Alloyed $(\mathrm{La}, \mathrm{Mg})_{2} \mathrm{Ni}_{7}$-Type Alloys
}

\author{
M. Balcerzak (D, M. Nowak, and M. Jurczyk
}

(Submitted January 5, 2018; in revised form April 23, 2018; published online September 26, 2018)

\begin{abstract}
The ( $\mathrm{La}, \mathrm{Mg})_{2} \mathrm{Ni}_{7}$-type alloys are candidates for hydrogen storage materials. In this study, mechanical alloying with subsequent annealing under the argon atmosphere at $1123 \mathrm{~K}$ for $0.5 \mathrm{~h}$ is applied to produce $\mathrm{La}_{1.5-x} \mathrm{Pr}_{x} \mathrm{Mg}_{0.5} \mathrm{Ni}_{7}$ and $\mathrm{La}_{1.5-x} \mathrm{Nd}_{x} \mathrm{Mg}_{0.5} \mathrm{Ni}_{7}$ alloys $(x=0,0.25,0.5,1)$. A shaker-type ball mill is used in the study. The objective of the present study is to investigate the influence of the amount of Pr or Nd in the La$\mathrm{Mg}-\mathrm{Ni}$ alloy on the electrochemical, hydrogenation and dehydrogenation properties of $(\mathrm{La}, \mathrm{Mg})_{2} \mathrm{Ni}_{7}$-type materials. The $x$-ray diffraction analysis reveals the formation of multi-phase structure materials. The obtained alloys were studied by a conventional Sievert's type apparatus at $303 \mathrm{~K}$. It has been observed that a chemical modification by Pr and Nd can affect the kinetics of the hydrogen absorption process and the maximum hydrogen storage capacity. Moreover, the stability of the electrochemical discharge capacity during cyclic work of the $(\mathrm{La}, \mathrm{Mg})_{2} \mathrm{Ni}_{7}$-type alloys is improved by a substitution with the $\mathrm{La}$ by $\mathrm{Pr}$ or $\mathrm{Nd}$ atoms.
\end{abstract}

Keywords energy, intermetallic, microscope electron, powder metallurgy, rare earths, x-ray

\section{Introduction}

The $\mathrm{La}_{2} \mathrm{Ni}_{7}$ intermetallic alloy of a superstacking structure (1:1 $\mathrm{LaNi}_{5}$ to $\mathrm{LaNi}_{2}$ slabs ratio) is characterized by greater $\mathrm{H}$ uptake than the $\mathrm{LaNi}_{5}$ phase. Therefore, it is attractive for hydrogen storage systems and for secondary $\mathrm{Ni}-\mathrm{MH}_{x}$ batteries as negative electrode materials (Ref 1,2). However, the practical use of this phase is limited due to several factors such as poor cycle stability of the electrochemical discharge capacity during the charging/discharging process.

There are several methods to improve the performance of hydrogen storage alloys, one of which is chemical modification. This approach is based on the fact that the final hydrogen storage properties of materials are directly related to the crystallographic structure and phase composition. It was revealed in the past that apartial substitution of the $\mathrm{A}$ and/or $\mathrm{B}$ atoms in $\mathrm{A}_{2} \mathrm{~B}_{7}$-type materials by rare earth and/or transition metals can affect their structure and phase composition and therefore improve the cycling stability, the diffusion rate, the maximum hydrogen storage capacity, etc. (Ref 1, 3-5). For example, the effect of the $\mathrm{Mg}$ content on the properties of the $\mathrm{La}_{2-x} \mathrm{Mg}_{x} \mathrm{Ni}_{7}$ system was investigated (Ref 6-8). The concentration of $\mathrm{Mg}$ in the basic system is very impactful on the final phase composition. It was shown that when $x=0.48-0.5$,

M. Balcerzak, M. Nowak, and M. Jurczyk, Institute of Materials Science and Engineering, Poznań University of Technology, Jana Pawla II no 24, 61-138 Poznan, Poland. Contact e-mail: mateusz.balcerzak@put.poznan.pl.

$x=0.6$ and $x>0.48$, the following main phases $(\mathrm{La}, \mathrm{Mg})_{2} \mathrm{Ni}_{7}$, (La, $\mathrm{Mg}) \mathrm{Ni}_{3}$ and $\mathrm{LaNi}_{5}$ were observed, respectively (Ref 7).

Moreover, the replacement of $\mathrm{La}$ by the $\mathrm{Pr}$ or $\mathrm{Nd}$ atoms in the La-Ni-based alloys can increase the hydrogen equilibrium pressure and improve the anti-corrosion ability (Ref 9-11). The $\mathrm{La}_{2} \mathrm{Ni}_{7}$-type materials chemically modified by $\mathrm{Nd}$ can be used as negative electrode materials in secondary $\mathrm{Ni}-\mathrm{MH}_{x}$ batteries characterized by an improved cyclic durability. These electrodes are characterized by an improved cyclic durability and can work below room temperature $(233 \mathrm{~K}$ ) (Ref 9). It is noteworthy that a partial substitution of La with the Pr atoms caused changes in the crystal structure of the $\mathrm{A}_{2} \mathrm{~B}_{7}$ alloys. For example, in the $\mathrm{La}_{0.8-x} \mathrm{Nd}_{x} \mathrm{Mg}_{0.2} \mathrm{Ni}_{3.1} \mathrm{Co}_{0.25} \mathrm{Al}_{0.15}$ alloys, the phase abundance of the $(\mathrm{La}, \mathrm{Mg})_{2} \mathrm{Ni}_{7}$ phase decreases from 71.32 to $42.70 \mathrm{wt} . \%$, while that of the $\mathrm{LaNi}_{5}$ phase increases from 26.01 to 51.64 wt.\% when $\mathrm{x}$ increases from 0 to 0.4 (Ref 12).

Among many methods of production of hydrogen storage materials, the $\mathrm{La}_{2} \mathrm{Ni}_{7}$-type alloys were mostly synthesized by conventional methods: vacuum magnetic levitation method (Ref 9), induction melting (Ref 1, 4, 10, 11, 13-15), melt spinning (Ref 16) or arc melting (Ref 2). However, still little is known about the $\mathrm{La}_{2} \mathrm{Ni}_{7}$-type alloys obtained by the mechanical alloying (MA) method, widely used in the past to obtain different types of non-equilibrium materials (Ref 3, 17). This process consists in repeated fracture, mixing and cold welding of a fine blend of elemental particles resulting in a size reduction and chemical reactions (Ref 18). As a non-equilibrium processing method, MA can be used to produce large quantities of materials at a relatively low cost. Recent studies suggest that the kinetics of hydrogen absorption and desorption of the alloys synthesized by MA can be significantly improved for large specific surface areas and a short hydrogen diffusion distance (Ref 19).

For this reason, in this work, MA and heat treatment were used to prepare the La-Pr-Mg-Ni and La-Nd-Mg-Ni alloys. The effect of substituting $\mathrm{La}$ with $\mathrm{Pr}$ or $\mathrm{Nd}$ on the hydrogenation 
and electrochemical properties of the La-Mg-Ni alloy has been presented and discussed. Moreover, it is noteworthy that in this work the authors focused on the effect of chemical modification in a simple La-Mg-Ni system [not complex as in previous works (Ref 9)]. The authors believe that the substitution of elements performed in simple systems can provide information on the accurate and direct impact of the La replacement with $\mathrm{Pr}$ and $\mathrm{Nd}$ on the hydrogen sorption and electrochemical properties of the $(\mathrm{La}, \mathrm{Mg})_{2} \mathrm{Ni}_{7}$-type materials.

\section{Experimental Details}

\subsection{Chemicals}

Applied commercial materials: La powder — grated from rod (Alfa Aesar, 99.9\%), Mg powder (Alfa Aesar, $45 \mu \mathrm{m}, 99.8 \%$ ), Ni powder (Aldrich, $5 \mu \mathrm{m}, 99.99 \%$ ), Pr powder-grated from rod (Alfa Aesar, 99.1\%), Nd powder-grated from rod (Alfa Aesar, 99.9\%).

All electrochemical measurements were taken in deaerated $6 \mathrm{M} \mathrm{KOH}$ solution prepared from the $\mathrm{KOH}$ flakes and $18 \mathrm{M} \Omega \mathrm{cm}^{-1}$ water.

\subsection{Preparation of Materials}

The $\mathrm{La}_{1.5-x} \mathrm{Pr}_{x} \mathrm{Mg}_{0.5} \mathrm{Ni}_{7}$ and $\mathrm{La}_{1.5-x} \mathrm{Nd}_{x} \mathrm{Mg}_{0.5} \mathrm{Ni}_{7}$ alloy powders $(x=0,0.25,0.5,1)$ were prepared by the MA and annealing processes. The elemental powders were weighted, blended and poured into vials in a glove box filled with the argon atmosphere. Mechanical alloying lasted $48 \mathrm{~h}$ in all cases and was carried out in the argon atmosphere. The ratio of the weight of the hard steel balls (12 $\mathrm{mm}$ in diameter) to the weight of powder was $4.2: 1$.

A heat treatment of the obtained as-milled powder materials was carried out in a furnace at $1123 \mathrm{~K}$ for $0.5 \mathrm{~h}$. This process was conducted in high-purity argon.

\subsection{Structure and Morphology Characterization}

The structure characterization of the obtained alloys was carried out to find a correlation between the structures of the alloys and their phase compositions with the observed hydrogenation and dehydrogenation characteristics.

A PANalytical Empyrean powder diffractometer $(\mathrm{CuK} \alpha$ radiation, $\lambda=1.54056 \AA$ ) was used to investigate the phase compositions of the materials after synthesis. The XRD measurements were taken at a room temperature with a voltage and anode current of $45 \mathrm{kV}$ and $40 \mathrm{~mA}$, respectively. The XRD profiles were refined with the Rietveld method using the Maud software.

The microstructure morphology of the obtained materials was determined by scanning electron microscopy (SEM)VEGA TS5135 TESCAN digital microscopy imaging.

\subsection{Electrochemical Measurements}

All synthesized samples with the addition of carbonyl nickel powder (10 wt.\%) were used as negative electrodes in the Ni$\mathrm{MH}_{x}$ systems. It is noteworthy that in this paper, the discharge capacities have been presented per unit gram of the measured material. A detailed description of the electrochemical measurements was included in the authors' previous work (Ref 8). The cycle stability of the materials was evaluated by the capacity retaining rate after 30 th and 50th cycles: $R=\left(C_{x}\right)$ $\left.C_{\max }\right) \times 100 \%$, where the $C_{x}$ and the $C_{\max }$ are discharge capacities at cycle $x(30,50)$ and maximum discharge capacity, respectively.

\subsection{Pressure-Composition-Isotherm (PCI) Tests}

The obtained La-Mg-Ni-type alloys were studied by a conventional Sievert's type PCI apparatus, Particulate Systems, HPVA-200 with a vacuum pump. The mass of the sample for each measurement run was approx. $0.6 \mathrm{~g}$. Before the hydrogen sorption-desorption measurements, no activation method was used. All alloys were degassed under vacuum at $303 \mathrm{~K}$ for $1 \mathrm{~h}$ before the tests.

Firstly, three cycles of hydrogen absorption kinetics measurements were performed under the hydrogen pressure of $3 \mathrm{MPa}$ at $303 \mathrm{~K}$. These studies also provided information on the activation properties of these materials. Between the cycles, the alloys were degassed at $673 \mathrm{~K}$. After the kinetic measurements, the degassed La-Mg-Ni-type materials were tested to obtain the pressure-composition-isotherm curves (at $303 \mathrm{~K}$ and under a hydrogen pressure range of up to approx. $7 \mathrm{MPa}$ ). A detailed description of the apparatus and the measurements has been presented in the authors' previous work (Ref 17).

\subsection{DSC Measurements}

All of the La-Mg-Ni-type materials after the PCT tests were tested by a TA DSC Q20 scanning calorimeter (DSC). The tests were performed up to $873 \mathrm{~K}$, with the heating rate of $10 \mathrm{~K} / \mathrm{min}$ in the argon atmosphere.

\section{Results and Discussion}

\subsection{Morphology, Structure and Phase Compositions}

Figure 1 presents the SEM images of the $\mathrm{La}_{1.0} \mathrm{Pr}_{0.5} \mathrm{Mg}_{0.5} \mathrm{Ni}_{7}$ alloy powders - one of the investigated ( $\mathrm{La}, \mathrm{Mg})_{2} \mathrm{Ni}_{7}$-type alloys. All alloys are composed of irregular porous particles. Moreover, all materials are characterized by a bimodal particle size distribution. The size of the alloy particles varies approximately from 100 to $800 \mu \mathrm{m}$. The rest of the particles have a size lower than $10 \mu \mathrm{m}$. (Part of them are attached to the surface of the larger particles.)

The authors did not observe any significant differences between the morphologies of the studied samples. The grains refinement after the substitution of $\mathrm{La}$ with $\mathrm{Pr}$ reported by Zhang et al. (Ref 16) for the melt-spun $\mathrm{A}_{2} \mathrm{~B}_{7}$-type alloys was not observed.

Figure 2 presents the XRD patterns of the $\mathrm{La}_{1.5-x} \mathrm{Pr}_{x} \mathrm{Mg}_{0.5}$ $\mathrm{Ni}_{7}$ and $\mathrm{La}_{1.5-x} \mathrm{Nd}_{x} \mathrm{Mg}_{0.5} \mathrm{Ni}_{7}$ alloy powders $(x=0,0.25,0.5,1)$ after $48 \mathrm{~h}$ of MA and an additional heat treatment at $1123 \mathrm{~K}$ for $0.5 \mathrm{~h}$ in high-purity argon. The most important data from the Rietveld refinement of the XRD patterns are presented in Table 1. Compared to the results reported by Xiangqian et al., the annealing process described in this paper appears to be more preferable. Alloys with the main $(\mathrm{La}, \mathrm{Mg})_{2} \mathrm{Ni}_{7}$-type phase are obtained after a heat treatment at lower temperatures. Moreover, the time of the heat treatment process is much shorter (Ref 9).

It can be easily seen that all of the samples had a multi-phase structure. The main phase in all alloys is the $(\mathrm{La}, \mathrm{Mg})_{2} \mathrm{Ni}_{7}$-type 

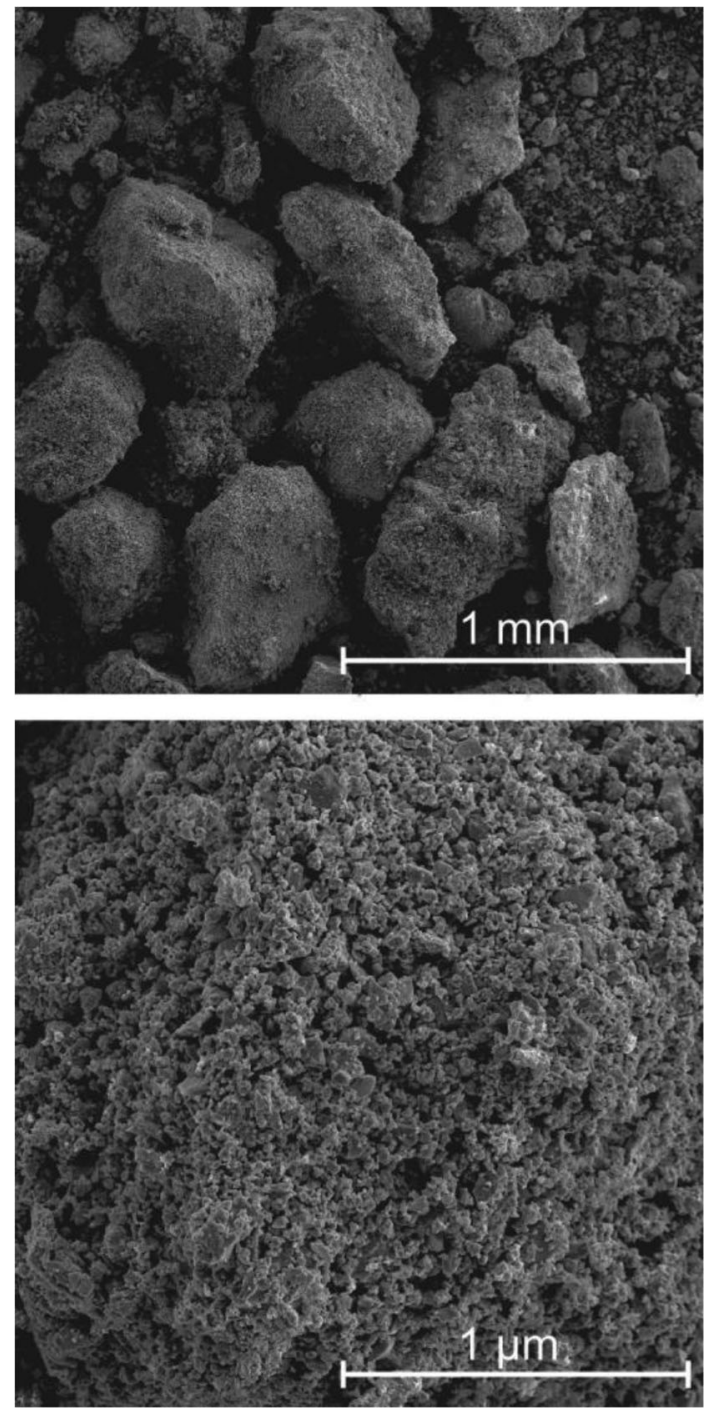

Fig. 1 SEM micrographs of $\mathrm{La}_{1.0} \mathrm{Pr}_{0.5} \mathrm{Mg}_{0.5} \mathrm{Ni}_{7}$ alloy obtained at different magnifications

one having a hexagonal structure crystallizing in the $\mathrm{P} 63 / \mathrm{mmc}$ space group $\left(\mathrm{Ce}_{2} \mathrm{Ni}_{7}\right.$-type $)$ - marked in Fig. 2 and Table 1 as $\mathrm{La}_{2} \mathrm{Ni}_{7}$-type $(\mathrm{H})$. The ( $\left.\mathrm{La}, \mathrm{Mg}\right)_{2} \mathrm{Ni}_{7}$-type phase is obtained by stacking two $\mathrm{AB}_{5}$ slabs with one $\mathrm{A}_{2} \mathrm{~B}_{4}$ (Ref 1,20). According to all the XRD patterns, no separate $\mathrm{La}, \mathrm{Pr}, \mathrm{Nd}, \mathrm{Mg}$ or $\mathrm{Ni}$ elements were found.

In addition to the main ( $\mathrm{La}, \mathrm{Mg})_{2} \mathrm{Ni}_{7}$-type phase, the unmodified $\mathrm{La}_{1.5} \mathrm{Mg}_{0.5} \mathrm{Ni}_{7}$ alloy is composed of two minor phases. The first one is the $\mathrm{LaNi}_{5}$-type phase having a hexagonal structure crystallizing in the $\mathrm{P} 6 / \mathrm{mmm}$ space group $\left(\mathrm{CaCu}_{5}\right.$-type). The second one is the rhombohedral $(\mathrm{La}, \mathrm{Mg})_{2}$ $\mathrm{Ni}_{7}$-type phase crystallizing in the R-3 m space group-marked in Fig. 2 and Table 1 as $\mathrm{La}_{2} \mathrm{Ni}_{7}$-type (R). The same phase composition was obtained by $\mathrm{Li}$ et al. (Ref 1 ) for inductive melted $\mathrm{La}_{0.60} \mathrm{R}_{0.20} \mathrm{Mg}_{0.20}(\mathrm{NiCoMnAl}){ }_{3.5}$ alloys $(\mathrm{R}=\mathrm{La}, \mathrm{Ce}$, $\mathrm{Pr}, \mathrm{Nd})$. However, the phase abundances are different than those presented in Table 1, which most likely results from different chemical compositions.

A partial substitution of La by the Pr atoms caused changes in the crystal structure of the alloys. The rhombohedral (La, Mg $)_{2} \mathrm{Ni}_{7}$-type phase is replaced with the $\mathrm{LaNi}_{3}$-type phase that crystallizes in the same space group $(\mathrm{R}-3 \mathrm{~m})$. The phase abundance of the main hexagonal (La, Mg) ${ }_{2} \mathrm{Ni}_{7}$-type phase increased, while the $\mathrm{LaNi}_{3}$-type phase decreased with increasing $\mathrm{Pr}$ content in the material. Moreover, the $\mathrm{LaNi}_{3}$-type phase is replaced by the $\mathrm{PrMgNi}_{4}$-type phase in $\mathrm{La}_{0.5} \mathrm{PrMg}_{0.5} \mathrm{Ni}_{7}$. The phase abundance of the $\mathrm{LaNi}_{5}$-type phase remains at the same level (1-2 wt.\%) regardless of the Pr content in the alloy.

The lattice parameters of all the $(\mathrm{La}, \mathrm{Mg})_{2} \mathrm{Ni}_{7}$-type, $\mathrm{LaNi}_{5}$ type and $\mathrm{LaNi}_{3}$-type phases were reduced with increasing $\mathrm{Pr}$ content in the alloy. It is due to the smaller atomic radius of $\mathrm{Pr}$ $(0.1828 \mathrm{~nm})$ compared to $\mathrm{La}(0.1877 \mathrm{~nm})$.

A partial substitution of $\mathrm{La}$ by the $\mathrm{Nd}$ atoms caused changes in the minor phase composition of the alloys. The $\mathrm{LaNi}_{5}$-type and the rhombohedral $(\mathrm{La}, \mathrm{Mg})_{2} \mathrm{Ni}_{7}$-type phases forming the unmodified $\mathrm{La}_{1.5} \mathrm{Mg}_{0.5} \mathrm{Ni}_{7}$ alloy are replaced by the $\mathrm{La}_{5} \mathrm{Ni}_{19^{-}}$ type phase in the Nd-containing alloys. It is noteworthy that the $\mathrm{La}_{5} \mathrm{Ni}_{19}$ theoretical hydrogen storage capacity is lower than that of $\mathrm{La}_{2} \mathrm{Ni}_{7}$. On the other hand, this phase is characterized by good catalytic properties (Ref 11). The phase abundance of the hexagonal (La,Mg) ${ }_{2} \mathrm{Ni}_{7}$-type phase increased, while the $\mathrm{La}_{5} \mathrm{Ni}_{19}$-type phase decreased with the increasing $\mathrm{Nd}$ content in the $\mathrm{La}_{1.5-x} \mathrm{Nd}_{x} \mathrm{Mg}_{0.5} \mathrm{Ni}$ material. Based on the XRD studies, we can conclude that the maximum content of the hexagonal $\mathrm{La}_{2} \mathrm{Ni}_{7}$-type phase is observed for the $\mathrm{La}_{0.5} \mathrm{Nd}_{1} \mathrm{Mg}_{0.5} \mathrm{Ni}_{7}$ alloy.

The lattice parameters of the hexagonal $(\mathrm{La}, \mathrm{Mg})_{2} \mathrm{Ni}_{7}$-type phase were firstly increased (for $\mathrm{La}_{1.25} \mathrm{Nd}_{0.25} \mathrm{Mg}_{0.5} \mathrm{Ni}_{7}$ ) and then decreased with increasing $\mathrm{Nd}$ content in the alloy. The authors think that the initial increase in the hexagonal ( $\mathrm{La}, \mathrm{Mg})_{2} \mathrm{Ni}_{7}$-type phase lattice parameters was caused by the change of the phase compositions occurring after a partial substitution of $\mathrm{La}$ with the $\mathrm{Nd}$ atoms, as described above. As was shown, the $\mathrm{La}_{1.5} \mathrm{Mg}_{05} \mathrm{Ni}_{7}$ alloy is composed of the hexagonal $\mathrm{La}_{2} \mathrm{Ni}_{7}$-type phase and two secondary phases. The authors think that until the material is partially composed of the secondary $\mathrm{LaNi}_{5}$-type and/or rhombohedral $\mathrm{La}_{2} \mathrm{Ni}_{7}$-type phase, the chemical composition of the hexagonal $\mathrm{La}_{2} \mathrm{Ni}_{7}$-type is depleted in lanthanum. After a partial substitution of La with the Nd atoms, a change in the secondary phases was observed. This change could cause a release of some of the La atoms embedded in the structure of minor phases prior to chemical modification. After a partial substitution, these La atoms could be incorporated into the main phase taking up the other atoms' place in the structure, thus creating the La-richer hexagonal $\mathrm{La}_{2} \mathrm{Ni}_{7}$-type phase. Because $\mathrm{La}$ has the largest atomic radius among the used elements, an increase in the lattice parameter was observed. To prove this claim, however, additional highquality structure measurements have to be taken.

The lattice parameters of the secondary $\mathrm{La}_{5} \mathrm{Ni}_{19}$-type phase decreased with increasing $\mathrm{Nd}$ content in the alloy. As in the case of $\mathrm{Pr}$, it is caused by a smaller atomic radius of $\mathrm{Nd}$ $(0.1821 \mathrm{~nm})$ compared to $\mathrm{La}(0.1877 \mathrm{~nm})$. The same phenomenon was observed in the past for Nd- and Pr-substituted La-Ni alloys (Ref 9, 14).

Because the chemical modification of $\mathrm{La}_{1.5} \mathrm{Mg}_{0.5} \mathrm{Ni}_{7}$ by $\mathrm{Pr}$ and $\mathrm{Nd}$ affected the lattice parameters of all phases, it can be stated that the Pr and $\mathrm{Nd}$ atoms co-form all of these phases. According to the work of Liu et al. (Ref 11), it can be concluded that the $\mathrm{Pr}$ and $\mathrm{Nd}$ atoms co-form an $\left[\mathrm{AB}_{5}\right]$ subunit instead of $\left[\mathrm{A}_{2} \mathrm{~B}_{4}\right]$. However, when the $\left[\mathrm{AB}_{5}\right]$ subunit of the superlattice phase is saturated (especially for Pr-rich and $\mathrm{Nd}$ rich samples), the extra $\mathrm{Pr}$ and $\mathrm{Nd}$ can co-form other minor phases. 

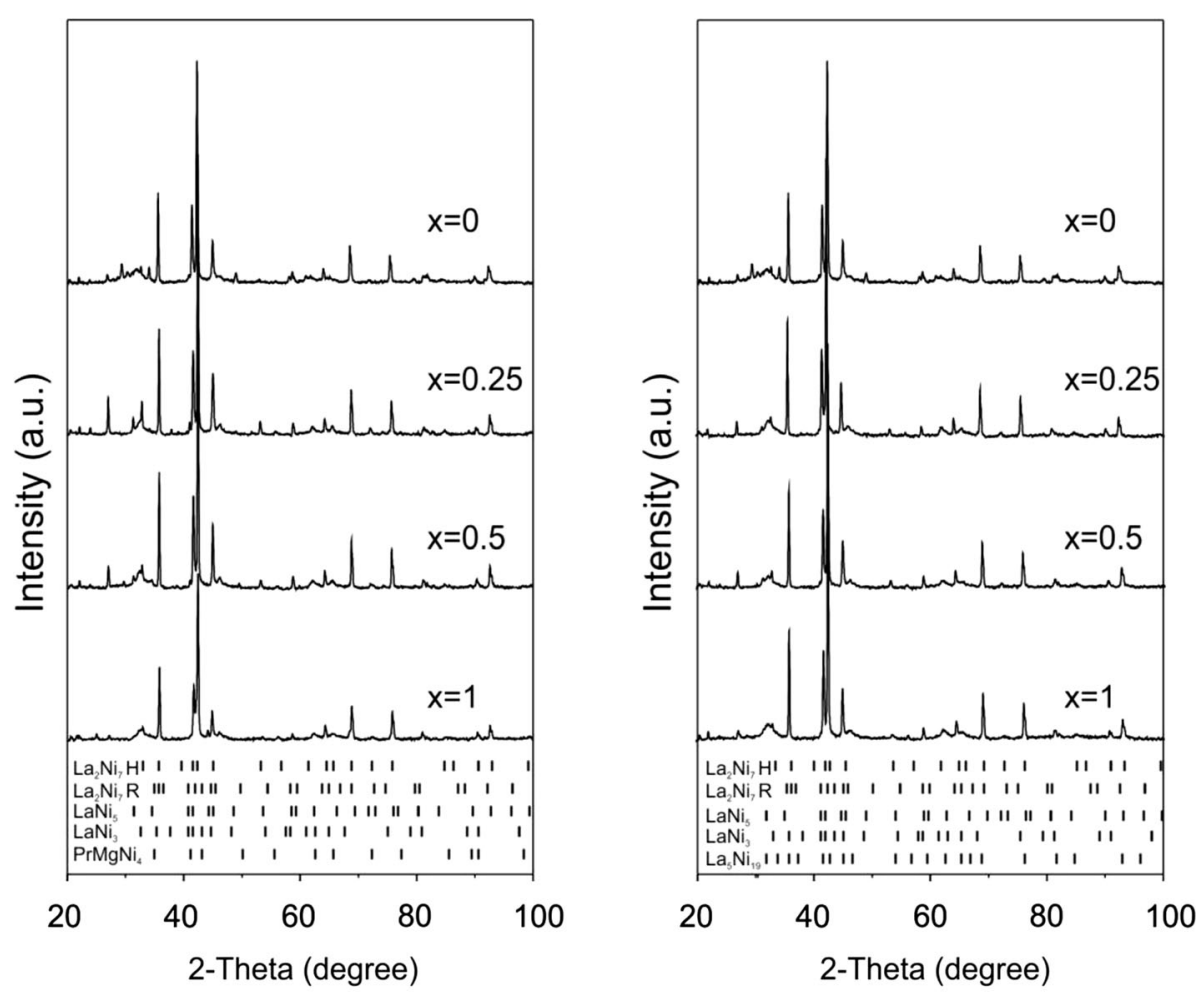

$\mathrm{La}_{1.5-\mathrm{x}} \mathrm{Pr}_{\mathrm{x}} \mathrm{Mg}_{0.5} \mathrm{Ni}_{7}$

$\mathrm{La}_{1.5-\mathrm{x}} \mathrm{Nd}_{x} \mathrm{Mg}_{0.5} \mathrm{Ni}_{7}$

Fig. 2 XRD patterns of $\mathrm{La}_{1.5-x} \mathrm{Pr}_{x} \mathrm{Mg}_{0.5} \mathrm{Ni}_{7}$ and $\mathrm{La}_{1.5-x} \mathrm{Nd}_{x} \mathrm{Mg}_{0.5} \mathrm{Ni}_{7}$ alloys after $48 \mathrm{~h}$ of $\mathrm{MA}$ process and additional heat treatment

Table 1 Phase structures of the $\mathrm{La}_{1.5-x} \mathrm{Pr}_{x} \mathrm{Mg}_{0.5} \mathrm{Ni}_{7}$ and $\mathrm{La}_{1.5-x} \mathrm{Nd}_{x} \mathrm{Mg}_{0.5} \mathrm{Ni}_{7}$ alloys

\begin{tabular}{|c|c|c|c|c|}
\hline \multirow[b]{2}{*}{ Sample } & \multirow[b]{2}{*}{ Phase } & \multicolumn{2}{|c|}{ Lattice parameter, $\AA$} & \multirow[b]{2}{*}{ Phase abundance, wt.\% } \\
\hline & & $a$ & $c$ & \\
\hline $\begin{array}{l}\mathrm{La}_{1.5} \mathrm{Mg}_{0.5} \mathrm{Ni}_{7} \\
R_{\mathrm{wp}}=9.15 \\
S=1.94\end{array}$ & $\begin{array}{l}\mathrm{La}_{2} \mathrm{Ni}_{7} \text {-type }(\mathrm{H}) \\
\mathrm{LaNi}_{5} \text {-type } \\
\mathrm{La}_{2} \mathrm{Ni}_{7} \text {-type }(\mathrm{R})\end{array}$ & $\begin{array}{l}5.0384 \\
5.2342 \\
5.0336\end{array}$ & $\begin{array}{r}24.1457 \\
4.0629 \\
36.2942\end{array}$ & $\begin{array}{r}89.98 \\
1.81 \\
8.21\end{array}$ \\
\hline $\begin{array}{l}\mathrm{La}_{1.25} \operatorname{Pr}_{0.25} \mathrm{Mg}_{0.5} \mathrm{Ni}_{7} \\
R_{\text {wp }}=9.34 \\
S=2.34\end{array}$ & $\begin{array}{l}\mathrm{La}_{2} \mathrm{Ni}_{7} \text {-type }(\mathrm{H}) \\
\mathrm{LaNi}_{5} \text {-type } \\
\mathrm{LaNi}_{3} \text {-type }\end{array}$ & $\begin{array}{l}5.0182 \\
5.1678 \\
5.0862\end{array}$ & $\begin{array}{r}24.1425 \\
3.9870 \\
25.0105\end{array}$ & $\begin{array}{r}93.90 \\
1.17 \\
4.93\end{array}$ \\
\hline $\begin{array}{l}\mathrm{LaPr}_{0.5} \mathrm{Mg}_{0.5} \mathrm{Ni}_{7} \\
R_{\mathrm{wp}}=9.49 \\
S=2.17\end{array}$ & $\begin{array}{l}\mathrm{La}_{2} \mathrm{Ni}_{7} \text {-type }(\mathrm{H}) \\
\mathrm{LaNi}_{5} \text {-type } \\
\mathrm{LaNi}_{3} \text {-type }\end{array}$ & $\begin{array}{l}5.0146 \\
5.1601 \\
5.0830\end{array}$ & $\begin{array}{r}24.1401 \\
3.9671 \\
24.9298\end{array}$ & $\begin{array}{r}95.42 \\
0.97 \\
3.61\end{array}$ \\
\hline $\begin{array}{l}\mathrm{La}_{0.5} \operatorname{PrMg}_{0.5} \mathrm{Ni}_{7} \\
R_{\mathrm{wp}}=9.33 \\
S=1.77\end{array}$ & $\begin{array}{l}\mathrm{La}_{2} \mathrm{Ni}_{7} \text {-type }(\mathrm{H}) \\
\mathrm{LaNi}_{5} \text {-type } \\
\text { PrMgNi }_{4} \text {-type }\end{array}$ & $\begin{array}{l}5.0059 \\
5.1589 \\
7.1016\end{array}$ & $\begin{array}{r}24.1367 \\
3.9412\end{array}$ & $\begin{array}{r}93.02 \\
1.03 \\
5.95\end{array}$ \\
\hline $\begin{array}{l}\mathrm{La}_{1.25} \mathrm{Nd}_{0.25} \mathrm{Mg}_{0.5} \mathrm{Ni}_{7} \\
R_{\mathrm{wp}}=9.12 \\
S=2.74\end{array}$ & $\begin{array}{l}\mathrm{La}_{2} \mathrm{Ni}_{7} \text {-type }(\mathrm{H}) \\
\mathrm{La}_{5} \mathrm{Ni}_{19} \text {-type }\end{array}$ & $\begin{array}{l}5.0336 \\
5.0655\end{array}$ & $\begin{array}{l}24.2519 \\
48.5512\end{array}$ & $\begin{array}{r}95.54 \\
4.46\end{array}$ \\
\hline $\begin{array}{l}\mathrm{LaNd}_{0.5} \mathrm{Mg}_{0.5} \mathrm{Ni}_{7} \\
R_{\mathrm{wp}}=9.65 \\
S=2.33\end{array}$ & $\begin{array}{l}\mathrm{La}_{2} \mathrm{Ni}_{7} \text {-type }(\mathrm{H}) \\
\mathrm{La}_{5} \mathrm{Ni}_{19} \text {-type }\end{array}$ & $\begin{array}{l}5.0176 \\
5.0556\end{array}$ & $\begin{array}{l}24.1549 \\
48.3706\end{array}$ & $\begin{array}{r}96.77 \\
3.23\end{array}$ \\
\hline $\begin{array}{l}\mathrm{La}_{0.5} \mathrm{NdMg}_{0.5} \mathrm{Ni}_{7} \\
R_{\mathrm{wp}}=9.35 \\
S=2.29\end{array}$ & $\begin{array}{l}\mathrm{La}_{2} \mathrm{Ni}_{7} \text {-type }(\mathrm{H}) \\
\mathrm{La}_{5} \mathrm{Ni}_{19} \text {-type }\end{array}$ & $\begin{array}{l}5.0006 \\
5.0283\end{array}$ & $\begin{array}{l}24.1380 \\
48.2309\end{array}$ & $\begin{array}{r}97.38 \\
2.62\end{array}$ \\
\hline
\end{tabular}


Phase compositions of the described $\mathrm{La}_{1.5-x} \mathrm{Nd}_{x} \mathrm{Mg}_{0.5} \mathrm{Ni}_{7}$ alloys differ from the compositions obtained in the past for the melted $\mathrm{La}_{0.8} \mathrm{Nd}_{x} \mathrm{Mg}_{0.2} \mathrm{Ni}_{3.1} \mathrm{Co}_{0.25} \mathrm{Al}_{0.15}$ samples (Ref 9). For these materials, instead of the $\mathrm{La}_{5} \mathrm{Ni}_{19}$-type minor phase, $\mathrm{LaNi}_{5}$-type and $\mathrm{LaMgNi}_{4}$-type phases were observed. It means that even a small chemical modification (in this case by the Co and $\mathrm{Al}$ atoms) can significantly affect the structure of the $\mathrm{A}_{2} \mathrm{~B}_{7}$ type alloys (Ref 9).

Based on the above-described XRD studies, it can be concluded that the substitution of $\mathrm{La}$ by $\mathrm{Pr}$ and $\mathrm{Nd}$ did not affect the change of the major phase. The addition of $\mathrm{Pr}$ and $\mathrm{Nd}$ stabilizes and increases the hexagonal $(\mathrm{La}, \mathrm{Mg})_{2} \mathrm{Ni}_{7}$-type phase abundance (Ref 15).

\subsection{Electrochemical Measurements}

The results of the electrochemical measurements taken on the $\mathrm{La}_{1.5-x} \mathrm{Pr}_{x} \mathrm{Mg}_{0.5} \mathrm{Ni}_{7}$ and $\mathrm{La}_{1.5-x} \mathrm{Nd}_{x} \mathrm{Mg}_{0.5} \mathrm{Ni}_{7}$ alloys are presented in Fig. 3. Moreover, the most important data from the electrochemical measurements are summarized in Table 2.

All of the electrodes displayed the maximum capacity at the first five cycles. The activation properties result from the phase composition and lattice parameters of the material. Such good activation properties were also observed for other La-Ni-type alloys, which means that this could be a common property of the $\mathrm{La}_{2} \mathrm{Ni}_{7}$-type materials (Ref $1,9,10$ ).

The maximum discharge capacity of the $\mathrm{La}_{1.5} \mathrm{Mg}_{0.5} \mathrm{Ni}_{7}$ alloy chemically modified by $\mathrm{Pr}$ is firstly reduced (for $\left.\mathrm{La}_{1.25} \mathrm{Pr}_{0.25} \mathrm{Mg}_{0.5} \mathrm{Ni}_{7}\right)$ and then increased to reach $308 \mathrm{mAh} / \mathrm{g}$ for the $\mathrm{La}_{0.5} \mathrm{PrMg}_{0.5} \mathrm{Ni}_{7}$ alloy. An opposite trend was observed for alloys modified by $\mathrm{Nd}$. The more the $\mathrm{Nd}$ in the alloy, the lower the discharge capacity. The best maximum discharge capacity $(311 \mathrm{mAh} / \mathrm{g})$ was obtained for the $\mathrm{La}_{1.25} \mathrm{Nd}_{0.25}$ $\mathrm{Mg}_{0.5} \mathrm{Ni}_{7}$ alloy characterized by the highest $\mathrm{La}_{5} \mathrm{Ni}_{19}$-type phase content. As was stated above, the $\mathrm{La}_{5} \mathrm{Ni}_{19}$ phase is characterized by very good catalytic properties. Moreover, studies on the electrochemical performance of the $\mathrm{A}_{2} \mathrm{~B}_{7}$-type single-phase $\mathrm{La}_{3} \mathrm{MgNi}_{14}$ alloy revealed that both the (La, Mg) $)_{5} \mathrm{Ni}_{19}$ and the $\mathrm{LaNi}_{5}$ phases have a catalytic effect on the fast discharge of the alloy (Ref 11).

The discharge capacities result from several factors such as phase composition and phase abundances. Moreover, the hydrogen uptake during charging is also strongly related to the cell volume of the main phase. A reduction of the cell volume may cause a decrease in the interstitial sites for hydrogen and thus reduce the discharge capacity. In this work, the authors showed that the chemical modification of the $\mathrm{La}_{1.5} \mathrm{Mg}_{0.5} \mathrm{Ni}_{7}$ alloy affects all the said factors: phase composition, phase abundances and cell volumes. The measured discharge capacities result from all of the factors, but the exact impact of each factor is unknown.

A substitution of the La by $\mathrm{Pr}$ or Nd elements resulted in increased cycle stability of the electrodes. The best cycle stability after 50 cycles was obtained for the alloys with the highest $\mathrm{Pr}$ and $\mathrm{Nd}$ content. After 50 cycles, the cycle stability of $\mathrm{MA}$ and annealed $\mathrm{La}_{0.5} \mathrm{PrMg}_{0.5} \mathrm{Ni}_{7}$ and $\mathrm{La}_{0.5} \mathrm{NdMg}_{0.5} \mathrm{Ni}_{7}$ reached 64 and $71 \%$, respectively. As was shown in the past, a partial substitution of $\mathrm{La}$ with rare earth elements is an effective way to improve the cycle life and high rate dischargeability.

The discharge capacities of all the studied alloys were degraded with the charge/discharge cycles. Most often, it was due to the following reasons:

- formation of stable hydride phases. However, as shown below, the PCT curves - studied alloy hydrides are unstable and can be mostly desorbed at the room temperature.

- partial oxidation of the electrode material. The degradation of the discharge capacity in the studied materials can originate from the formation and thickening of the $\mathrm{Mg}(\mathrm{OH})_{2}$ and $\mathrm{La}(\mathrm{OH})_{3}$ surface layers, that hinder the electron and mass transfer and consume the active material (Ref 11, 21). $\mathrm{Wu}$ et al. observed that $\mathrm{La}$ and $\mathrm{Mg}$ in the $\mathrm{La}-\mathrm{Mg}-\mathrm{Ni}$ alloys can be oxidized after approx. 10 cycles of charging/discharging. La, however, can be oxidized easier $\left(\mathrm{La}(\mathrm{OH})_{3}\right)$ than $\mathrm{Mg}$ in the $\mathrm{KOH}$ electrolyte $\left(\mathrm{Mg}(\mathrm{OH})_{2}\right)$ (Ref 10). Recently, it has been demonstrated that the $\mathrm{Nd}$ and $\operatorname{Pr}$ addition suppresses the oxidation of hydrogen-absorbing alloys (Ref 4, 13).

- pulverization of alloy particles caused by expansion and contraction of the cell volume during hydrogenation and dehydrogenation (Ref 22). This process not only increases the contact resistance between the alloy particles but also exposes smaller particles to the corrosion/oxidation of alkaline electrolyte (Ref 11). It also accelerates the oxidation and diffusion of rare earth elements toward the surface. During the charge/discharge process, the rare earth elements tend to diffuse toward the surface of the alloys, and the disproportion is determined by the atom concentration, the melting point and the cell volume (Ref 1). The $\mathrm{Nd}$ substitution can suppress the oxidation of the elements

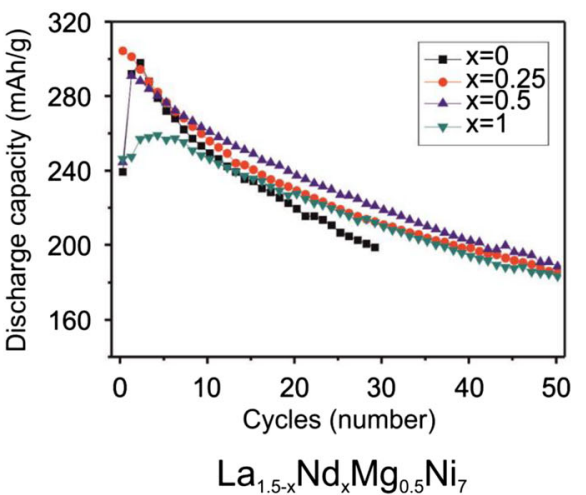

Fig. 3 Discharge capacities as a function of charging/discharging cycle number of electrodes prepared with $\mathrm{La}_{1.5-x} \mathrm{Pr}_{x} \mathrm{Mg}_{0.5} \mathrm{Ni}_{7}$ and $\mathrm{La}_{1.5-x} \mathrm{Nd}_{x} \mathrm{Mg}_{0.5} \mathrm{Ni}_{7}$ alloys 
Table 2 Summarized data from electrochemical measurements on $\mathrm{La}_{1.5-x} \mathrm{Pr}_{x} \mathrm{Mg}_{0.5} \mathrm{Ni}_{7}$ and $\mathrm{La}_{1.5-x} \mathrm{Nd}_{x} \mathrm{Mg}_{0.5} \mathrm{Ni}_{7}$ alloys

\begin{tabular}{lccc}
\hline Sample & $\boldsymbol{A}_{\text {cycles-echem }}$ & Maximum discharge capacity, mAh/g & Capacity retaining rate after 30th/50th cycle, \% \\
\hline $\mathrm{La}_{1.5} \mathrm{Mg}_{0.5} \mathrm{Ni}_{7}$ & 3 & 304 & $67 / \ldots$ \\
$\mathrm{La}_{1.25} \mathrm{Pr}_{0.25} \mathrm{Mg}_{0.5} \mathrm{Ni}_{7}$ & 2 & 265 & $71 / 58$ \\
$\mathrm{LaPr}_{0.5} \mathrm{Mg}_{0.5} \mathrm{Ni}_{7}$ & 2 & 282 & $74 / 60$ \\
$\mathrm{La}_{0.5} \mathrm{PrMg}_{0.5} \mathrm{Ni}_{7}$ & 1 & 308 & $72 / 64$ \\
$\mathrm{La}_{1.25} \mathrm{Nd}_{0.25} \mathrm{Mg}_{0.5} \mathrm{Ni}_{7}$ & 1 & 311 & $70 / 61$ \\
$\mathrm{LaNd}_{0.5} \mathrm{Mg}_{0.5} \mathrm{Ni}_{7}$ & 2 & 297 & $76 / 65$ \\
$\mathrm{La}_{0.5} \mathrm{NdMg}_{0.5} \mathrm{Ni}_{7}$ & 5 & 265 & $82 / 71$ \\
$A_{\text {cycles-echem }}-$ number of activation cycles needed to obtain best electrochemical properties & \\
\hline
\end{tabular}

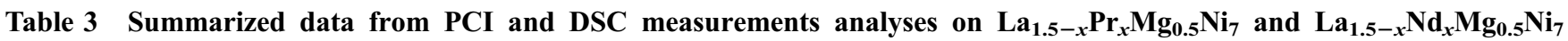
alloys

\begin{tabular}{|c|c|c|c|c|c|c|c|c|}
\hline \multirow[b]{3}{*}{ Sample } & \multicolumn{7}{|c|}{ Kinetic measurements } & \multirow[b]{3}{*}{$T_{\text {H-des }}, \mathbf{K}$} \\
\hline & \multirow[b]{2}{*}{$A_{\text {cycles }}$} & \multicolumn{3}{|c|}{$H_{\text {kin }}$, wt. $\%$} & \multicolumn{3}{|c|}{$T_{95}, \min$} & \\
\hline & & 1 cycle & 2 cycle & 3 cycle & 1 cycle & 2 cycle & 3 cycle & \\
\hline $\mathrm{La}_{1.5} \mathrm{Mg}_{0.5} \mathrm{Ni}_{7}$ & 2 & 1.60 & 1.59 & 1.59 & 301 & 13 & 13 & 404.2 \\
\hline $\mathrm{La}_{1.25} \mathrm{Pr}_{0.25} \mathrm{Mg}_{0.5} \mathrm{Ni}_{7}$ & 3 & 1.42 & 1.42 & 1.36 & 281 & 9 & 5 & 413.3 \\
\hline $\mathrm{LaPr}_{0.5} \mathrm{Mg}_{0.5} \mathrm{Ni}_{7}$ & 1 & 1.47 & 1.29 & 1.38 & 10 & 86 & 51 & 423.7 \\
\hline $\mathrm{La}_{0.5} \operatorname{PrMg}_{0.5} \mathrm{Ni}_{7}$ & 2 & 1.47 & 1.49 & 1.50 & 188 & 12 & 13 & 472.4 \\
\hline $\mathrm{La}_{1.25} \mathrm{Nd}_{0.25} \mathrm{Mg}_{0.5} \mathrm{Ni}_{7}$ & 2 & 1.53 & 1.49 & 1.48 & 101 & 4 & 5 & 519.2 \\
\hline $\mathrm{LaNd}_{0.5} \mathrm{Mg}_{0.5} \mathrm{Ni}_{7}$ & 3 & 1.38 & 1.45 & 1.44 & 342 & 5 & 4 & 459.6 \\
\hline $\mathrm{La}_{0.5} \mathrm{NdMg}_{0.5} \mathrm{Ni}_{7}$ & 2 & 1.38 & 1.40 & 1.39 & 252 & 4 & 11 & 429.2 \\
\hline \multicolumn{9}{|c|}{$\begin{array}{l}H_{\text {kin }} \text { - hydrogen concentration from kinetic measurements } \\
T_{95} \text { - time needed to reach } 95 \% \text { of maximum hydrogen capacity } \\
A_{\text {cycles }} \text {-number of activation cycles needed to obtain best kinetic properties } \\
T_{\text {H-des }}\left({ }^{\circ} \mathrm{C}\right) \text { - hydrogen desorption peak temperature }\end{array}$} \\
\hline
\end{tabular}

due to its slower diffusion in materials caused by a much higher melting point (Ref 1). The influence of the pulverization effect apparently depends on the number of charging/discharging cycles.

Because the Nd and Pr addition suppresses the oxidation to the hydrogen-absorbing elements such as $\mathrm{Mg}$ and $\mathrm{La}$, it can be concluded that the pulverization should be the dominant factor of the reduction of the discharge capacity (Ref 14). It is noteworthy that the cell volume expansion rate of the $\mathrm{LaNi}_{5}$ phase is different from those of the superstacking phases - the discrete expansion leads to a serious pulverization and capacity degradation (Ref 11).

\subsection{Hydrogen Absorption-Desorption Properties}

Manometric, Sievert's type device was used to measure PCI and the kinetic properties of all the studied alloys. The most important data obtained from these studies are summarized in Table 3.

Figure 4 presents the time-capacity curves of the $\mathrm{La}_{1.5-x} \mathrm{Pr}_{x} \mathrm{Mg}_{0.5} \mathrm{Ni}_{7}$ and $\mathrm{La}_{1.5-x} \mathrm{Nd}_{x} \mathrm{Mg}_{0.5} \mathrm{Ni}_{7}$ alloys in the activation/kinetic measurements obtained at $303 \mathrm{~K}$. These studies were conducted without any activation procedure. It can be seen that all of the alloys need to be activated before they obtain the best kinetic properties. Moreover, for most of the samples the hydrogenation process in the first cycle was initiated after some incubation time. (The only exception was the $\mathrm{LaPr}_{0.5} \mathrm{Mg}_{0.5} \mathrm{Ni}$ alloy.) In the following cycles, the hydrogen sorption started immediately after filling the reaction chamber with hydrogen. The best hydrogenation properties were obtained in the second or third cycle. This means that all of the materials need to be activated. However, the process of activation is much easier compared to what described by Zhang et al. (Ref 15) described for inductive melted Pr-Mg-Ni alloys - those samples were four times hydrided (2 MPa, $1 \mathrm{~h}$ ) and dehydrided (0.0001 MPa, $1 \mathrm{~h})$ at $318 \mathrm{~K}$.

The chemical substitution of La with Pr and Nd affected the kinetics of the hydrogen sorption. A partial replacement of La with the $\mathrm{Nd}$ atoms is effective in the reduction of time needed for the hydrogen absorption. Time needed to reach $95 \%$ of the maximum hydrogen capacity is reduced from $13 \mathrm{~min}$ for unmodified $\mathrm{La}_{1.5} \mathrm{Mg}_{0.5} \mathrm{Ni}_{7}$ to $4-5 \mathrm{~min}$ for the Nd-containing alloys. Such good properties should be connected to the presence of the $\mathrm{La}_{5} \mathrm{Ni}_{19}$-type minor phase characterized by good catalytic properties.

The maximum hydrogen storage capacity strongly resulting from the structure and phase composition of the alloy was reduced after a chemical modification by $\mathrm{Pr}$ and $\mathrm{Nd}$. This reduction is caused by the shrinkage of the cell volume caused by a partial substitution of $\mathrm{La}$ with the $\mathrm{Pr}$ and $\mathrm{Nd}$ atoms (Table 1). In smaller cells, the interstitial sites for hydrogen are smaller and the insertion of hydrogen is harder, thus leading to the reduction of the hydrogen storage capacity. The highest value was obtained for the unmodified $\mathrm{La}_{1.5} \mathrm{Mg}_{0.5} \mathrm{Ni}_{7}$ alloy-1.6 wt.\%. 

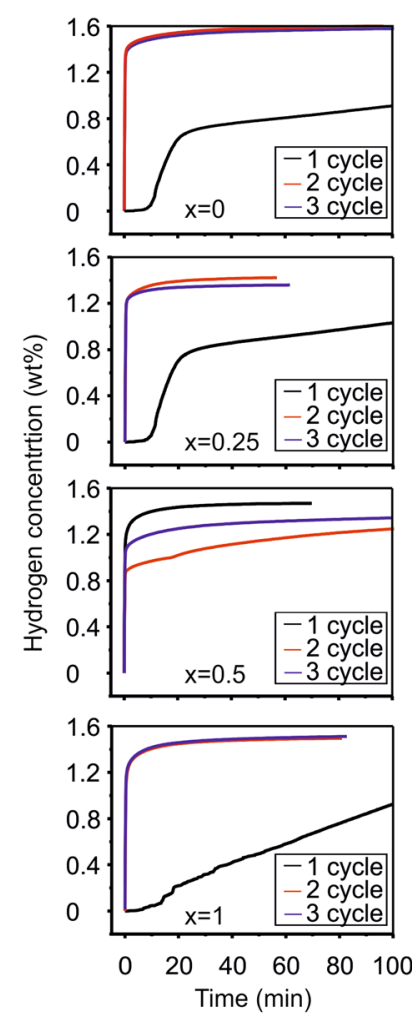

$$
\mathrm{La}_{1.5-\mathrm{x}} \mathrm{Pr}_{x} \mathrm{Mg}_{0.5} \mathrm{Ni}_{7}
$$

Fig. 4 Time-capacity curves of $\mathrm{La}_{1.5-x} \mathrm{Pr}_{x} \mathrm{Mg}_{0.5} \mathrm{Ni}_{7}$ and $\mathrm{La}_{1.5-x} \mathrm{Nd}_{x} \mathrm{Mg}_{0.5} \mathrm{Ni}_{7}$ alloys in activation/kinetic measurements

Figure 5 presents a comparison of the PCI curves obtained for all the studied alloys. These curves show that all materials actively absorb hydrogen at $303 \mathrm{~K}$. For all samples, an absorption plateau region (which is very flat) was observed. This region corresponds to the transformation from the $\alpha$-solid solution of hydrogen in the intermetallic alloy to the $\beta$-hydride phase. Despite the fact that the alloys are multi-phase, only one plateau region is visible for each sample. It is caused by a low secondary phase abundance. Moreover, the equilibrium pressures of the $A_{2} B_{7}$ and $A_{5} B_{19}$ phases are very close due to their similar superstacking structures (Ref 11).

The plateau pressure heavily depends on the stability of the metal hydride, which results from the unit cell volume. It was previously shown that increasing the $\mathrm{Mg}$ content in the $\mathrm{La}_{2-x} \mathrm{Mg}_{x} \mathrm{Ni}_{7}$ alloy leads to an increase in the plateau pressure until it reaches the level of $10 \mathrm{MPa}$ for $x=1.0$ (Ref 14).

The plateau pressure (sorption process) observed on the PCT curves of the $\mathrm{La}_{1.5-x} \mathrm{Pr}_{x} \mathrm{Mg}_{0.5} \mathrm{Ni}_{7}$ alloys increases with increasing Pr content in the sample, to reach the highest value for $\mathrm{La}_{0.5} \mathrm{PrMg}_{0.5} \mathrm{Ni}_{7}$. This increase is related to the reduction of the cell volume-in smaller cells the interstitial sites for hydrogen are smaller and the insertion of hydrogen is harder. Therefore, the plateau pressure increases. The result is a decreased stability of the hydride phase. For $\mathrm{La}_{0.5} \mathrm{PrMg}_{0.5} \mathrm{Ni}_{7}$, a decrease in the plateau pressure was observed-as caused by the change in the phase composition.

The chemical modification of the $(\mathrm{La}, \mathrm{Mg})_{2} \mathrm{Ni}_{7}$-type alloy by the $\mathrm{Nd}$ atoms also caused a change in the plateau pressure firstly decreased for $\mathrm{La}_{1.25} \mathrm{Nd}_{0.25} \mathrm{Mg}_{0.5} \mathrm{Ni}_{7}$ (caused by the
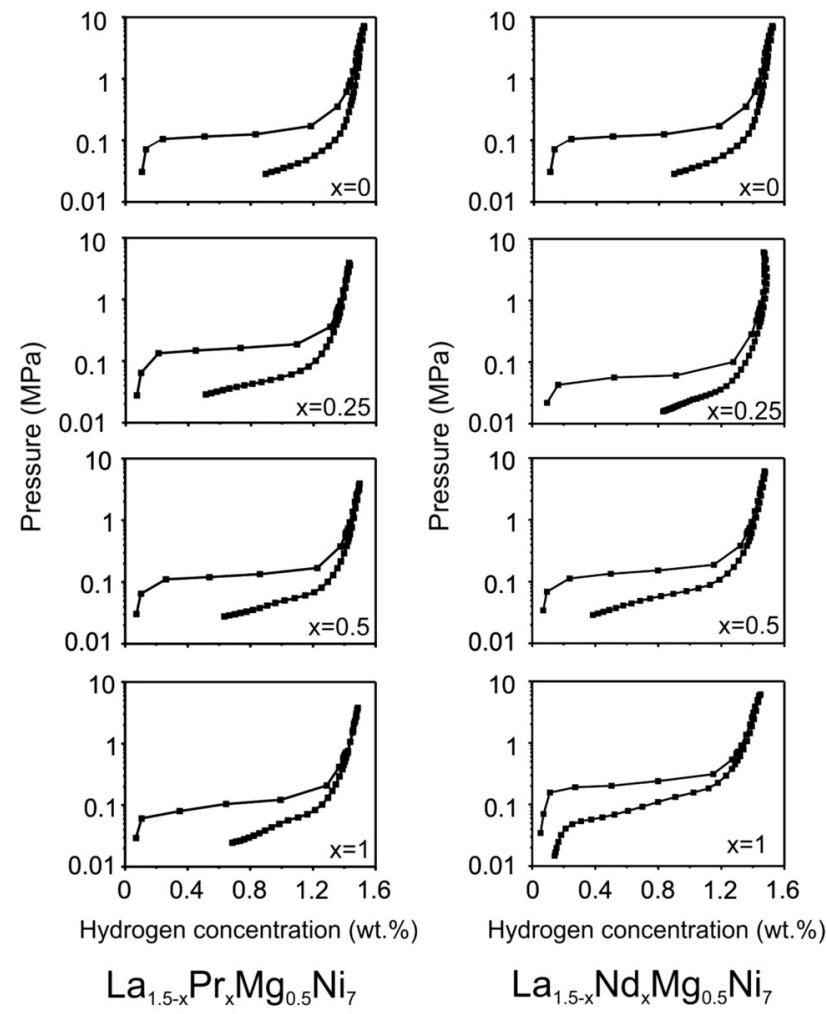

Fig. $5 \mathrm{PC}$ isotherms at $303 \mathrm{~K}$ of $\mathrm{La}_{1.5-x} \mathrm{Pr}_{x} \mathrm{Mg}_{0.5} \mathrm{Ni}_{7}$ and $\mathrm{La}_{1.5-x} \mathrm{Nd}_{x} \mathrm{Mg}_{0.5} \mathrm{Ni}_{7}$ alloys

change in the phase composition-replacement of the $\mathrm{LaNi}_{5}$ type and rhombohedral $\mathrm{La}_{2} \mathrm{Ni}_{7}$-type minor phases by the $\mathrm{La}_{5} \mathrm{Ni}_{19}$-type minor phase) and then increased with increasing content of the $\mathrm{Nd}$ atoms in the $\mathrm{La}_{1.5-x} \mathrm{Nd}_{x} \mathrm{Mg}_{0.5} \mathrm{Ni}_{7}$ alloys. This increase was caused by the shrinkage of the cell volume (as was in the case of the modification by Pr described above).

The sorption plateau pressure for all of the studied samples has a level close to the atmospheric pressure, which is best in terms of their application. Due to the very low pressure of the desorption plateau for most of the samples, it is not possible to determine the reversibility of the hydriding-dehydriding process. (The low-pressure end of the plateau region is not visible.) Between the absorption and the desorption curves, a hysteresis appeared. It is most likely due to the transformation strains resulting from the cell volume expansion and the contraction (that cannot be relaxed) during the formation of hydrides formation and the decomposition.

The observed hysteresis can be used to predict the pulverization rate of the alloy during cycling. Alloys with a larger hysteresis have higher pulverization rates during the hydride/dehydride cycling (Ref 15).

All the materials after the PCI measurements were also studied by the DSC method - the obtained profiles are presented in Fig. 6. Additionally, the hydrogen desorption peak temperatures are listed in Table 3. All of the curves were characterized by one endothermic peak corresponding to the desorption of hydrogen from the alloys (hydrogen that was undesorbed during the PCI measurements). It can be seen that the hydrogen desorption peak temperature heavily depends on the phase composition. A partial substitution of La with Pr caused an increase in the hydrogen desorption peak tempera- 

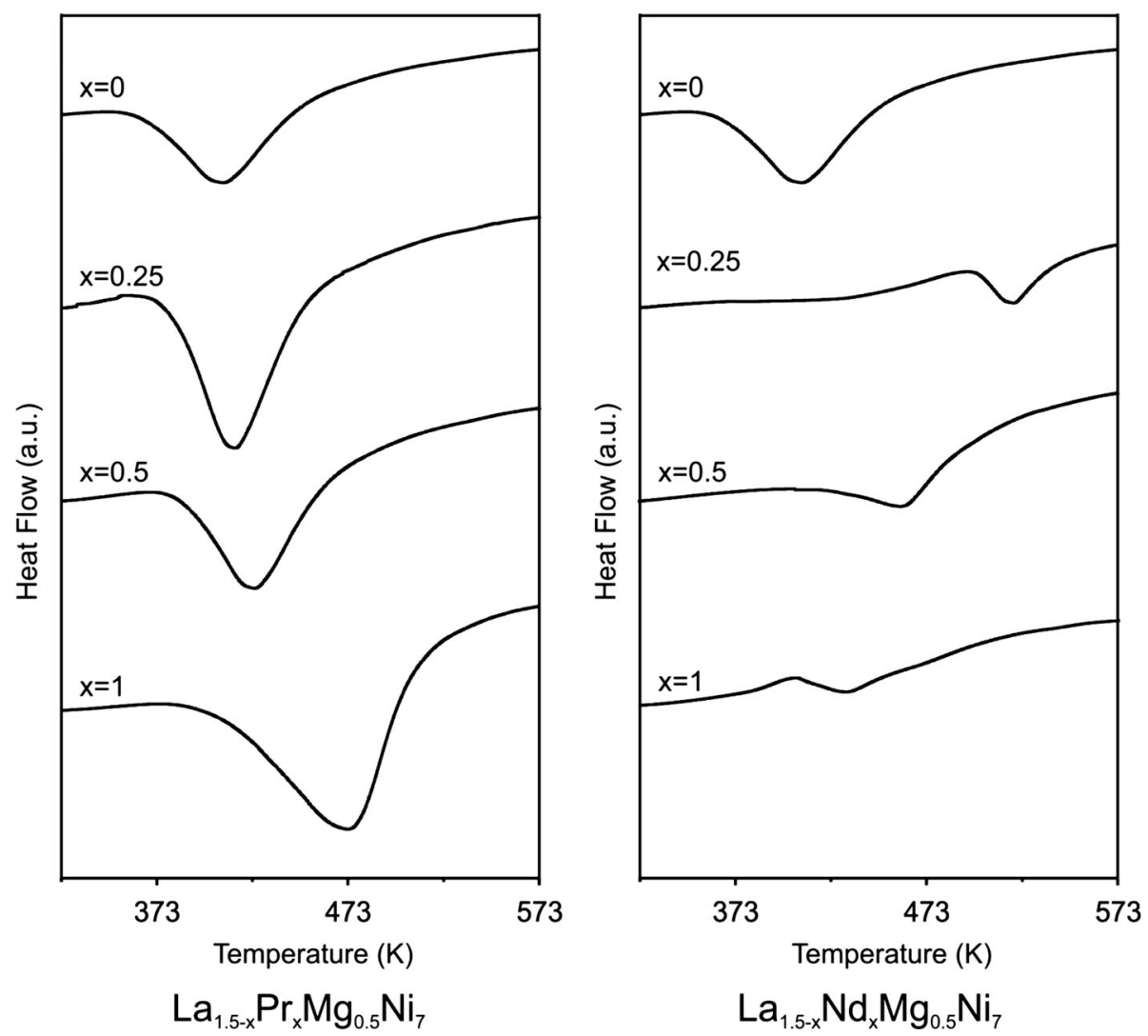

Fig. 6 DSC profiles of the hydrides of $\mathrm{La}_{1.5-x} \mathrm{Pr}_{x} \mathrm{Mg}_{0.5} \mathrm{Ni}_{7}$ and $\mathrm{La}_{1.5-x} \mathrm{Nd}_{x} \mathrm{Mg}_{0.5} \mathrm{Ni}_{7}$ alloys (after PCT tests)

ture. The hydride stability of the Nd-containing alloys increased with the higher content of the $\mathrm{La}_{5} \mathrm{Ni}_{19}$-type minor phase.

\section{Conclusions}

The $\mathrm{La}_{1.5-x} \mathrm{Pr}_{x} \mathrm{Mg}_{0.5} \mathrm{Ni}_{7}$ and $\mathrm{La}_{1.5-x} \mathrm{Nd}_{x} \mathrm{Mg}_{0.5} \mathrm{Ni}_{7}$ alloys $(x=0,0.25,0.5,1)$ were effectively prepared by the MA and annealing processes. The structure, microstructure, electrochemical and hydrogen storage properties of these materials were carefully investigated.

The studies of the authors revealed that the substitution of $\mathrm{La}$ with $\mathrm{Pr}$ or $\mathrm{Nd}$ did not affect the change of the major phase- $(\mathrm{La}, \mathrm{Mg})_{2} \mathrm{Ni}_{7}$ is the main phase in all the studied alloys. The phase compositions of the studied alloys, however, depend on the content of the $\mathrm{Pr}$ or $\mathrm{Nd}$ atoms in the alloys.

It was clearly demonstrated that a partial substitution of $\mathrm{La}$ in $\mathrm{La}_{1.5} \mathrm{Mg}_{0.5} \mathrm{Ni}_{7}$ can improve the electrochemical and hydrogen sorption properties of the $(\mathrm{La}, \mathrm{Mg})_{2} \mathrm{Ni}_{7}$-type system. The substitution of La with the $\mathrm{Pr}$ or $\mathrm{Nd}$ elements resulted in an increased cycle stability of the electrodes. The best cycle stability was obtained for the alloys with the highest Pr and $\mathrm{Nd}$ contents. Moreover, the chemical substitution of La with $\mathrm{Pr}$ or $\mathrm{Nd}$ also affected the kinetics of the hydrogen sorption and reduced the time of the hydrogenation process. The time needed to obtain $95 \%$ of the maximum hydrogen capacity at the 3rd cycle decreased to $4 \mathrm{~min}$ for the $\mathrm{LaNd}_{0.5} \mathrm{Mg}_{0.5} \mathrm{Ni}_{7}$ alloy. The hydrogen sorption properties of the ( $\mathrm{La}, \mathrm{Mg})_{2} \mathrm{Ni}_{7}$-type alloys presented in the paper are related to the changes in the crystal structure (cell volume) and phase composition of the materials.

\section{Acknowledgment}

This work was supported by the National Science Centre, Poland (No. 2014/15/B/ST8/00088).

\section{Open Access}

This article is distributed under the terms of the Creative Commons Attribution 4.0 International License (http://creativecommons.org/ licenses/by/4.0/), which permits unrestricted use, distribution, and reproduction in any medium, provided you give appropriate credit to the original author(s) and the source, provide a link to the Creative Commons license, and indicate if changes were made.

\section{References}

1. Y. Li, D. Han, S. Han, X. Zhu, L. Hu, Z. Zhang et al., Effect of Rare Earth Elements on the Electrochemical Properties of La-Mg-Ni-Based Hydrogen Storage Alloys, Int. J. Hydrogen Energy, 2009, 34, p 13991404

2. V.A. Yartys, A.B. Riabov, R.V. Denys, M. Sato, and R.G. Delaplane, Novel Intermetallic Hydrides, J Alloys Compd., 2006, 408-412, p $273-$ 279

3. T. Huang, X. Yuan, J. Yu, Z. Wu, J. Han, G. Sun et al., Effect of Annealing Treatment and Partial Substitution of $\mathrm{Cu}$ for Co on Phase Composition and Hydrogen Storage Performance of $\mathrm{La}_{0.7} \mathrm{Mg}_{0.3} \mathrm{Ni}_{3.2}$ $\mathrm{Co}_{0.35}$ Alloy, Int. J. Hydrogen Energy, 2012, 37, p 1074-1079 
4. T. Zhai, T. Yang, Z. Yuan, and Y. Zhang, An Investigation on Electrochemical and Gaseous Hydrogen Storage Performances of Ascast $\mathrm{La}_{1-x} \mathrm{Pr}_{x} \mathrm{MgNi}_{3.6} \mathrm{Co}_{0.4}(x=0-0.4)$ Alloys, J Hydrogen Energy, 2014, 39, p 14282-14287

5. T. Zhai, T. Yang, Z. Yuan, X. Sheng, W. Bu, Y. Qi et al., Influence of Hydrogen-Induced Amorphization and Annealing Treatment on Gaseous Hydrogen Storage Properties of $\mathrm{La}_{1-x} \mathrm{Pr}_{x} \mathrm{MgNi}_{3.6} \mathrm{Co}_{0.4}$ $(x=0-0.4)$ Alloys, J Alloys Compd., 2016, 639, p 15-20

6. X.G. Zhao and L.Q. Ma, Recent Progress in Hydrogen Storage Alloys for Nickel/Metal Hydride Secondary Batteries-Review, Int. J. Hydrogen Energy, 2009, 34, p 4788-4796

7. L. Zhang, S. Han, Y. Li, S. Yang, X. Zhao, and J. Liu, Effect of Magnesium on the Crystal Transformation and Electrochemical Properties of $\mathrm{A}_{2} \mathrm{~B}_{7}$-Type Metal Hydride Alloys, J. Elektrochem. Soc., 2004, 161, p A1844-A1850

8. M. Balcerzak, M. Nowak, and M. Jurczyk, Hydrogenation and Electrochemical Studies of La-Mg-Ni Alloys, Int. J. Hydrogen Energy, 2017, 42, p 1436-1443

9. S. Xiangqian, C. Yungui, T. Mingda, W. Chaoling, D. Gang, and K Zhenzhen, The Structure and $233 \mathrm{~K}$ Electrochemical Properties of $\mathrm{La}_{0.8-x} \mathrm{Nd}_{x} \mathrm{Mg}_{0.2} \mathrm{Ni}_{3.1} \mathrm{Co}_{0.25} \mathrm{Al}_{0.15} \quad(x=0.0-0.4)$ Hydrogen Storage Alloys, Int. J. Hydrogen Energy, 2009, 34, p 2661-2669

10. C. Wu, L. Zhang, J. Liu, Y. Li, S. Yang, B. Liu, and S. Han, Electrochemical Characteristics of $\mathrm{La}_{0.59} \mathrm{Nd}_{0.14} \mathrm{Mg}_{0.27} \mathrm{Ni}_{3.3}$ Alloy with Rhombohedral-Type and Hexagonal-Type $\mathrm{A}_{2} \mathrm{~B}_{7}$ Phases, J. Alloys Compd., 2017, 639, p 573-581

11. J. Liu, S. Han, Y. Li, S. Yang, X. Chen, C. Wu, and C. Ma, Effect of Pr on Phase Structure and Cycling Stability of La-Mg-Ni-Based Alloys with $\mathrm{A}_{2} \mathrm{~B}_{7}$ - and $\mathrm{A}_{5} \mathrm{~B}_{19}$-Type Superlattice Structures, Electrochemica Acta, 2015, 184, p 257-263

12. S. Ma, M. Gao, R. Li, H. Pan, and Y. Lei, A Study on the Structural and Electrochemical Properties of $\mathrm{La}_{0.7-x} \mathrm{Nd}_{x} \mathrm{Mg}_{0.3} \mathrm{Ni}_{2.45} \mathrm{Co}_{0.75} \mathrm{Mn}_{0.1} \mathrm{Al}_{0.2}$ $(x=0.0-3.0)$ Hydrogen Storage Alloys, J. Alloys Compd., 2008, 457, p $457-464$

13. J. Wang, S. Han, Y. Li, J. Liu, L. Che, L. Zhang, and J. Zhanf, Study of Phase Formation Mechanism and Electrochemical Properties of
$\mathrm{La}_{0.75-x} \mathrm{Nd}_{x} \mathrm{Mg}_{0.25} \mathrm{Ni}_{3,3}(x=0,0.15)$ Alloys Prepared by Powder Sintering, J. Alloys Compd., 2014, 582, p 552-557

14. V. Yartys and R. Denys, Structure-Properties Relationship in $\mathrm{RE}_{3-x} \mathrm{Mg}_{x} \mathrm{Ni}_{9} \mathrm{H}_{10-13}(\mathrm{RE}=\mathrm{La}, \mathrm{Pr}, \mathrm{Nd})$ Hydrides for Energy Storage, J. Alloys Compd., 2015, 645, p S412-S418

15. L. Zhang, W. Du, S. Han, Y. Li, S. Yang, Y. Zhao, C. Wu, and H. $\mathrm{Mu}$, Study on Solid Solubility of $\mathrm{Mg}$ in $\operatorname{Pr}_{3-x} \mathrm{Mg}_{x} \mathrm{Ni}_{9}$ and Electrochemical Properties of $\mathrm{PuNi}_{3}$-Type Single-Phase RE-Mg-Ni $(\mathrm{RE}=\mathrm{La}, \mathrm{Pr}, \mathrm{Nd})$ Hydrogen Storage Alloys, Electrochemica Acta, 2015, 173, p 200-208

16. Y. Zhang, H. Ren, B. Li, S. Guo, Q. Wang, and X. Wang, Structures and Electrochemical Hydrogen Storage Behaviours of $\mathrm{La}_{0.75-x} \mathrm{Pr}_{x} \mathrm{Mg}_{0.25} \mathrm{Ni}_{3.2} \mathrm{Co}_{0.2} \mathrm{Al}_{0.1}(x=0-0.4)$ Alloys Prepared by Melt Spinning, Int. J. Hydrogen Energy, 2009, 34, p 6335-6342

17. M. Balcerzak, J. Jakubowicz, T. Kachlicki, and M. Jurczyk, Hydrogenation Properties of Nanostructured $\mathrm{Ti}_{2} \mathrm{Ni}$-Based Alloys and Composites, J. Power Sources, 2015, 280, p 435-445

18. M. Nowak and M. Jurczyk, Nanotechnology for the storage of hydrogen, Nanotechnology for Energy Sustainability, Vol 2, R. Baldev, M. Van de Voorde, and Y. Mahajan, Ed., Wiley, New York, 2017, p 433-458. ISBN: 978-3-527-34014-9

19. X. Ma, X. Xie, P. Liu, L. Xu, and T. Liu, Synerginc Catalytic Effect of $\mathrm{Ti}$ Hydride and $\mathrm{Nb}$ Nanoparticles for Improving Hydrogenation and Dehydrogenation Kinetics of Mg-Based Nanocomposite, Prog. Nat. Sci. Mater. Int., 2017, 27, p 99-104

20. H.L. Chu, S.J. Qui, Q.F. Tian, L.X. Sun, Y. Zhao, F. Xu et al., Effect of Ball-Milling Time on the Electrochemical Properties of La-Mg-NiBased Hydrogen Storage Composite Alloys, Int. J. Hydrogen Energy, 2007, 32, p 4925-4932

21. M. Dornheim, S. Doppiu, G. Barkhordarian, U. Boesenberg, T. Klassen, O. Gutfleich et al., Hydrogen Storage in Magnesium-Based Hydrides and Hydride Composites, Scr. Mater, 2017, 56, p 841846

22. F. Zhang, Y. Luo, D. Wang, R. Yan, L. Kang, and J. Chen, Structure and Electrochemical Properties of $\mathrm{La}_{2-\mathrm{x}} \mathrm{Mg}_{x} \mathrm{Ni7.0} \quad(x=0.3-0.6)$ Hydrogen Storage Alloys, J. Alloys Compd., 2007, 439, p 181-188 